\title{
An Investigation Regarding the Preservice Teachers' Emotional Literacy Levels and Self-Efficacy Beliefs
}

\author{
Seval Eminoğlu Kü̧̈üktepe ${ }^{1}$, Müge Akbağ ${ }^{1} \&$ Esra Eminoğlu Özmercan ${ }^{2}$ \\ ${ }^{1}$ Atatürk Faculty of Education, Marmara University, İstanbul, Turkey \\ ${ }^{2}$ Ministry of National Education, İstanbul, Turkey \\ Correspondence: Seval Eminoğlu Küçüktepe, Atatürk Faculty of Education, Marmara University, İstanbul, \\ Turkey. Tel: 90-216-345-4705. E-mail: sevalek@marmara.edu.tr
}

Received: June 9, 2017

Accepted: June 25, 2017

Online Published: August 2, 2017

doi:10.5539/jel.v6n4p267

URL: http://doi.org/10.5539/jel.v6n4p267

\begin{abstract}
Self-efficacy beliefs and emotional literacy skills are considered as one of the most fundamental characteristics of teachers to create positive effects on students. The aim of this study is to investigate the relationship between preservice teachers' self-efficacy beliefs and their emotional literacy levels. This study is designed as a relational survey model research. Study group consisted of 318 volunteer preservice teachers who are fourth graders at education faculty in a state university in the West of Turkey, in 2015-2016 academic year. Teacher Efficacy Scale, Emotional Literacy Scale and Personal Information Form were used to collect data. The results of this study are that according to the gender, there is a significant difference in favor of female preservice teachers in social competence subscale and total score of emotional literacy scale; according to the departments preservice teachers are educated, there is a significant difference in emotional awareness and emotional self-efficacy subscales of emotional literacy scale; on the basis of the gender, preservice teachers' self-efficacy levels differ significantly in favor of female preservice teachers in teaching competency/external factors subscale and total score of the scale; according to the departments preservice teachers are educated, there is a significant difference in preservice teachers' self-efficacy levels in teaching competency/external factors subscale; and finally there is a positive relationship between preservice teachers' emotional literacy levels and their self-efficacy belief levels.
\end{abstract}

Keywords: social learning theory, transactional analysis, self-efficacy beliefs, emotional literacy, preservice teacher

\section{Introduction}

Self-efficacy is defined by Bandura (1986) as self judgements regarding organizing events to show performance and being able to accomplish it successfully. He also considers this trait as a powerful trait shaping one's behaviors. Self-efficacy is studied under a profession, it means how those who has the profession are equipped with the necessary knowledge and skills, and how they show the affective features necessary and how sufficient they see themselves in their profession.

Teachers play a crucial role on students' personal development. As teachers' weak personality may cause failures and educational traumas, teachers are expected to have powerful personalities and be sufficient in their job (Türkoğlu, 1990; Brophy, 1981; Bloom, 1979). Teachers' professional and personal features have a direct effect on the qualification of teaching and learning process.

One of the prominent features that a teacher is supposed to have in order to create positive effects on their students is their self-efficacy beliefs in teaching and learning processes (Doruk \& Kaplan, 2012; Louis \& Mistelethe, 2011; Yıldırım, 2011; Dede, 2008; Swars, Hart, Smith S., Smith M., \& Tolar, 2007; Erden, 2005; Ada \& Ünal, 2004; Kü̧̈ükahmet, 2000; Büyükkaragöz, 1998). When the literature is reviewed, it is found out that there are researches that state a positive relationship between teachers' self-efficacy beliefs and their students' academic success (Özdemir, 2008; Smith, 1996; Hoy \& Woolfolk, 1990; Peterson, Fennema, Carpenter, \& Loef, 1989).

Another feature that teachers are expected to have in order to promote a powerful learning for students is emotional literacy skills. Emotional literacy concept is first used in 1970s by Claude Steiner (2003), transactional 
analysis theorist, and defined as knowing of our feelings in a way to improve the life qualities and personal power of our and people around us.

Five major skills have been identified by Steiner $(2003,1996)$ who has done extensive research on teaching emotional literacy which are "being aware of own feelings, developing sincere empathy, managing emotions, restoring emotional damages and developing emotional interaction". It is expressed by Steiner that emotional literacy is often grounded on the feeling "love"; in other words, it is heart-centered. Although emotional literacy is often used instead of emotional intelligence, there are differences between these two concepts. It is also stated by Bocchino (1999) that emotional intelligence is a potential from the birth while emotional literacy is skills that can be developed afterwards and is about the perception and control of affective processes. Weare (2004), on the other hand, discusses the use of "intelligence" and defend that social and emotional capacity come from the birth and cannot be taught. Instead, he proposes to use the term "emotional literacy" and defines it as "...ability to understand ourselves and other people, and in particular to be aware of, understand, and use information about the emotional states of ourselves and others with competence" (Weare, 2004, p. 2).

When the literature regarding the "emotional literacy" is reviewed, it can be seen that most of the researches are focused on children and young people (Matsumoto, 2012; Kandemir \& Dündar, 2008; Antidote, 2003; Liau A. K., Liau A. W., Teoh, \& Liau M., 2003). Besides, some researches that were done with grown-ups and teachers revealed that emotional literacy is related to some other psychological variables such as coping behavior, general well-being, emotional well-being, etc. (Chan, 2008; Adeyemo, 2007; Carmeli, Yitzhak-Halevy, \& Weisberg, 2009).

While there has been studies in the literature investigated the relationship between teachers' and preservice teachers' self-efficacy beliefs and emotional intelligences (Şenel, Adiloğulları, \& Ulucan, 2014; Hashemi, 2011; Salami, 2007), any research focusing on the relationship between preservice teachers' self-efficacy beliefs and emotional literacy has not been encountered. That's why, this study is considered important as it provides contribution the literature. The aim of the research is to determine the relationship between preservice teachers' self-efficacy beliefs and emotional literacy levels. The questions which are related to the main aim of this research are as presented:

1) Do the scores of preservice teachers' emotional literacy show significant difference according to the gender?

2) Do the scores of preservice teachers' emotional literacy show significant difference according to the department?

3) Do the scores of preservice teachers' self-efficacy show difference according to the gender?

4) Do the scores of preservice teachers' self-efficacy show difference according to the department?

5) Is there a relationship between the preservice teachers' scores obtained from Emotional Literacy Scale and Teacher Efficacy Scale?

\section{Method}

This study is designed as a relational survey model. Survey research are used to describe a situation as it is now or it was in the past. Relational model, however, are aimed to present the presence or level of covariance of two or more variables (Karasar, 2005).

\subsection{Participants}

Study group consisted of 318 fourth grade volunteer preservice teachers who are from a public university in the West of Turkey. Preservice teachers who attended the research are $65 \%$ females and 35\% males. Distribution of the participants according to the departments is as follows; $8.2 \%$ from English language teaching, $4.4 \%$ from chemistry teacher education, $6.6 \%$ from art and crafts teacher education, $5.3 \%$ from mathematics teacher education, $9.4 \%$ from elementary teacher education, $14.5 \%$ from science and technology teacher education, $6.9 \%$ from music teacher education, $6.9 \%$ from French language teaching, $12.3 \%$ from Turkish language and literature teaching, $7.2 \%$ from history teacher education, $4.7 \%$ from biology teacher education, $8.5 \%$ from geography teacher education, $5 \%$ from computer and instructional technologies teacher education.

\subsection{Data Collection Tools}

\subsubsection{Teacher Efficacy Scale}

The first data collection tool is used to determine the teachers' self-efficacy. The scale was adopted by Diken (2005). Construct validity was investigated via explanatory factor analysis after the Turkish translation. According to the analysis results, 16 items out of 21 in original scale were decided to be used in Turkish form. 
There are two dimensions in the scale; general teaching efficacy/external factors and personal teaching efficacy/internal factors. Maximum score that one can get from the scale is 80 while the minimum is 16 . As the score gets higher, the teachers' self-efficacy levels rise. Cronbach Alpha was used for reliability test. The internal consistency coefficient of the scale is 0.71 .

\subsubsection{Emotional Literacy Scale}

The second scale used in this study is Emotional Literacy Scale developed by Akbağ, Eminoğlu-Küçüktepe and Eminoğlu-Özmercan (2016). As a result of the explanatory and confirmatory factor analysis, the scale has 34 items. This likert scale has five subscales which are emotional awareness, social competence, understanding emotions, emotional self-efficacy and regulating emotions. The Cronbach Alpha coefficient for the scale is 0.80 . Test re-test analysis was carried out 15 days break to 45 people. The test re-test coefficient is 0.89 . Minimum score that can be obtained from the scale is 34 while the maximum is 170 . As the score from the scale rises, emotional literacy level rises.

\subsubsection{Personal Information Form}

Personal Information Form is also used to gather information about the gender and the department preservice teachers are educated.

\subsection{Collection and Analysis of Data}

Teacher Efficacy Scale, Emotional Literacy Scale and Personal Information form were applied by the researchers. The scales were completed in approximately 40 minutes by preservice teachers. Preservice teachers are provided with the information regarding the aim and the importance of the study and the data from the scales. They are told to not to leave any questions unanswered. They are also informed that there are no true or false answers; thus, they do not need to worry but to mark the closest statement to them. Preservice teachers are also informed about the privacy of the data.

Pearson Correlation Coefficient is used in data analysis to calculate the relationship between the Teacher Efficacy Scale and Emotional Literacy Scale. Independent sample $t$ test is performed to investigate the difference of total and subscale scores of Teacher Efficacy Scale and Emotional Literacy Scale according to the gender. One-Way Analysis Variance (ANOVA) is used to investigate the difference of total and subscale scores of Teacher Efficacy Scale and Emotional Literacy Scale according to the department preservice teachers are educated.

\section{Results}

Data gathered in the research process are presented as the research questions presented. Whether the preservice teachers' Emotional Literacy scores differ according to the gender is analyzed via independent sample $t$ test. The results are as shown in Table 1.

Table 1. Results of independent sample t-test to determine whether the Emotional Literacy Scale scores differ according to the gender

\begin{tabular}{|c|c|c|c|c|c|c|c|c|}
\hline \multicolumn{2}{|c|}{ Emotional Literacy Scale } & \multirow{3}{*}{$\begin{array}{l}\text { Gender } \\
\text { Female } \\
\text { Male }\end{array}$} & \multirow{3}{*}{$\begin{array}{l}\mathrm{N} \\
207 \\
111\end{array}$} & \multirow{3}{*}{$\begin{array}{l}\bar{X} \\
3.696 \\
3.638\end{array}$} & \multirow{2}{*}{$\begin{array}{l}\mathrm{Sd} \\
0.374\end{array}$} & \multirow{3}{*}{$\begin{array}{l}\mathrm{df} \\
316\end{array}$} & \multirow{3}{*}{$\begin{array}{l}\mathrm{t} \\
1.277\end{array}$} & \multirow{3}{*}{$\begin{array}{l}\mathrm{p} \\
0.203\end{array}$} \\
\hline \multirow{2}{*}{1.} & \multirow{2}{*}{ Subscale: Emotional Awareness } & & & & & & & \\
\hline & & & & & 0.389 & & & \\
\hline & \multirow{2}{*}{ Subscale: Social Competence } & Female & 207 & 3.851 & 0.347 & \multirow{2}{*}{316} & \multirow{2}{*}{3.967} & \multirow{2}{*}{$0.000 *$} \\
\hline & & Male & 111 & 3.681 & 0.373 & & & \\
\hline \multirow{2}{*}{3.} & \multirow{2}{*}{ Subscale: Understanding Emotions } & Female & 207 & 3.446 & 0.400 & \multirow{2}{*}{316} & \multirow{2}{*}{0.379} & \multirow{2}{*}{0.705} \\
\hline & & Male & 111 & 3.428 & 0.389 & & & \\
\hline \multirow{2}{*}{4.} & \multirow{2}{*}{ Subscale: Emotional Self-Efficacy } & Female & 207 & 2.777 & 0.379 & \multirow{2}{*}{316} & \multirow{2}{*}{0.973} & \multirow{2}{*}{0.332} \\
\hline & & Male & 111 & 2.732 & 0.400 & & & \\
\hline & \multirow{2}{*}{ Subscale: Regulating Emotions } & Female & 207 & 2.663 & 0.428 & \multirow{2}{*}{316} & \multirow{2}{*}{-1.448} & \multirow{2}{*}{0.149} \\
\hline & & Male & 111 & 2.745 & 0.508 & & & \\
\hline \multirow{2}{*}{\multicolumn{2}{|c|}{ Total Score }} & Female & 207 & 3.391 & 0.182 & \multirow{2}{*}{316} & \multirow{2}{*}{2.793} & \multirow{2}{*}{$0.006^{*}$} \\
\hline & & Male & 111 & 3.329 & 0.192 & & & \\
\hline
\end{tabular}


Table 1 presents the finding whether there is a significant difference in emotional literacy scale scores according to the gender. As shown in Table 1, there shows a significant difference in the second subscale which is social competence and in the total score. This difference is in favor of female preservice teachers $(\bar{X}=3.85)$ in social competence subscale $(\mathrm{t}=3.967 ; \mathrm{p}<0.05)$. There is also another significant difference in favor of female $(\bar{X}=3.39)$ preservice teachers in total score $(\mathrm{t}=2.793 ; \mathrm{p}<0.05)$.

One-Way Analysis of Variance (ANOVA) is used to investigate the difference of total and subscale scores of Teacher Efficacy Scale and Emotional Literacy Scale according to the department preservice teachers are educated. Table 2 shows the ANOVA results carried out to investigate whether the scores from emotional literacy scale differ according to the department.

Table 2. Results of ANOVA to determine whether the Emotional Literacy Scale Scores Differ according to the department

\begin{tabular}{|c|c|c|c|c|c|c|c|c|c|}
\hline Emotional & Literacy Scale & Variance origin & $\begin{array}{l}\text { Sum } \\
\text { Squares }\end{array}$ & & df & Mean Square & $\mathrm{F}$ & $\mathrm{p}$ & $\begin{array}{l}\text { Significant } \\
\text { difference }\end{array}$ \\
\hline \multirow[t]{3}{*}{1.} & Subscale: & Between groups & 3.200 & & 12 & 0.267 & & & \multirow{3}{*}{$\begin{array}{l}\text { Music Teaching } \\
\text {-CIT }\end{array}$} \\
\hline & Emotional & Within groups & 42.626 & & 305 & 0.140 & 1.908 & $0.033^{*}$ & \\
\hline & Awareness & Total & 45.826 & & 317 & & & & \\
\hline \multirow{3}{*}{2} & \multirow{3}{*}{$\begin{array}{l}\text { Subscale: Social } \\
\text { Competence }\end{array}$} & Between groups & 1.069 & & 12 & 0.089 & & & \multirow{15}{*}{$\begin{array}{l}\text { CIT- } \\
\text { History Teaching }\end{array}$} \\
\hline & & Within groups & 41.190 & & 305 & 0.135 & 0.659 & 0.790 & \\
\hline & & Total & 42.259 & & 317 & & & & \\
\hline \multirow[t]{3}{*}{3.} & Subscale: & Between groups & 2.234 & & 12 & 0.186 & & & \\
\hline & Understanding & Within groups & 47.491 & & 305 & 0.156 & 1.196 & 0.285 & \\
\hline & Emotions & Total & 49.725 & & 317 & & & & \\
\hline \multirow[t]{3}{*}{4.} & \multirow{3}{*}{$\begin{array}{l}\text { Subscale: } \\
\text { Emotional } \\
\text { Self-Efficacy }\end{array}$} & Between groups & 4.106 & & 12 & 0.342 & \multirow{3}{*}{2.408} & \multirow{3}{*}{$0.005^{*}$} & \\
\hline & & Within groups & 43.334 & & 305 & 0.142 & & & \\
\hline & & Total & 47.440 & & 317 & & & & \\
\hline \multirow{3}{*}{5.} & \multirow{3}{*}{$\begin{array}{l}\text { Subscale: } \\
\text { Regulating } \\
\text { Emotions }\end{array}$} & Between groups & 3.295 & & 12 & 0.275 & \multirow{3}{*}{1.318} & \multirow{3}{*}{0.207} & \\
\hline & & Within groups & 63.547 & & 305 & 0.208 & & & \\
\hline & & Total & 66.842 & & 317 & & & & \\
\hline \multirow{3}{*}{\multicolumn{2}{|c|}{ Total Score }} & Between groups & 0.471 & & 12 & 0.039 & & & \\
\hline & & Within groups & 10.745 & & 305 & 0.035 & 1.114 & 0.348 & \\
\hline & & Total & 11.216 & & 317 & & & & \\
\hline
\end{tabular}

$* \mathrm{p}<0.05$

As shown in Table 2, there is no significant difference according to the departments in social competence, understanding emotions and regulating emotions subscales and in total score of Emotional Literacy Scale. However, scores in the emotional awareness subscale show significant difference according to the department $[\mathrm{F}(12-305)=1.908 ; \mathrm{p}<0.05]$. Also, scores in the emotional self-efficacy subscale show significant difference according to the department $[\mathrm{F}(12-305)=2.408 ; \mathrm{p}<0.05]$. Bonferroni post-hoc analysis is applied to detect the variance origin. The results show that for emotional awareness subscale, music teaching preservice teachers have higher scores than computer and instructional technologies preservice teachers (CIT). On the other hand, in emotional self-efficacy subscale computer and instructional technologies department preservice teachers gained higher scores from history teaching preservice teachers.

The result in Table 3 shows the $t$ test finding for the scores in Teacher Efficacy Scale according to the gender. 
Table 3. Results of independent sample t-test to determine whether the Teacher Efficacy Scale scores differ according to the gender

\begin{tabular}{|c|c|c|c|c|c|c|c|c|c|c|}
\hline \multicolumn{4}{|c|}{ Teacher Efficacy Scale } & \multirow{3}{*}{$\begin{array}{l}\text { Gender } \\
\text { Female } \\
\text { Male }\end{array}$} & \multirow{2}{*}{$\begin{array}{l}\mathrm{N} \\
207\end{array}$} & \multirow{2}{*}{$\begin{array}{l}\bar{X} \\
3.208\end{array}$} & \multirow{2}{*}{$\begin{array}{l}\mathrm{Sd} \\
0.437\end{array}$} & \multirow{3}{*}{$\begin{array}{l}\mathrm{df} \\
316\end{array}$} & \multirow{3}{*}{$\begin{array}{l}\mathrm{t} \\
2.325\end{array}$} & \multirow{3}{*}{$\begin{array}{l}\mathrm{p} \\
0.021^{*}\end{array}$} \\
\hline 1. & Subscale: & General & Teaching & & & & & & & \\
\hline & Efficacy/E & 1 Factors & & & 111 & 3.093 & 0.412 & & & \\
\hline \multirow[t]{2}{*}{2.} & Subscale: & Personal & Teaching & Female & 207 & 3.666 & 0.388 & \multirow{2}{*}{316} & \multirow{2}{*}{0.655} & \multirow{2}{*}{0.513} \\
\hline & Efficacy/I & Factors & & Male & 111 & 3.638 & 0.394 & & & \\
\hline \multirow{2}{*}{\multicolumn{3}{|c|}{ Total Score }} & & Female & 207 & 3.319 & 0.327 & \multirow{2}{*}{316} & \multirow{2}{*}{2.196} & \multirow{2}{*}{$0.029 *$} \\
\hline & & & & Male & 111 & 3.234 & 0.331 & & & \\
\hline
\end{tabular}

$* p<0.05$.

Table 3 shows whether the scores from Teacher Efficacy Scale according to the gender. When Table 3 is investigated, it is seen that there are significant differences according to the gender in general teaching efficacy/external factors and in total score of the scale. This significant difference in general teaching efficacy/external factors are in favor of female preservice teachers ( $X=3.85, \mathrm{t}=2.325 ; \mathrm{p}<0.05)$. The significant difference in total scale score is again in favor of female preservice teachers $(X=3.39 ; \mathrm{t}=2.196 ; \mathrm{p}<0.05)$.

One-Way Analysis of Variance (ANOVA) is used to determine the difference of total and subscale scores of Teacher Efficacy Scale according to the department. The findings are as in Table 4.

Table 4. Results of ANOVA to determine whether the Teacher Efficacy Scale scores differ according to the department

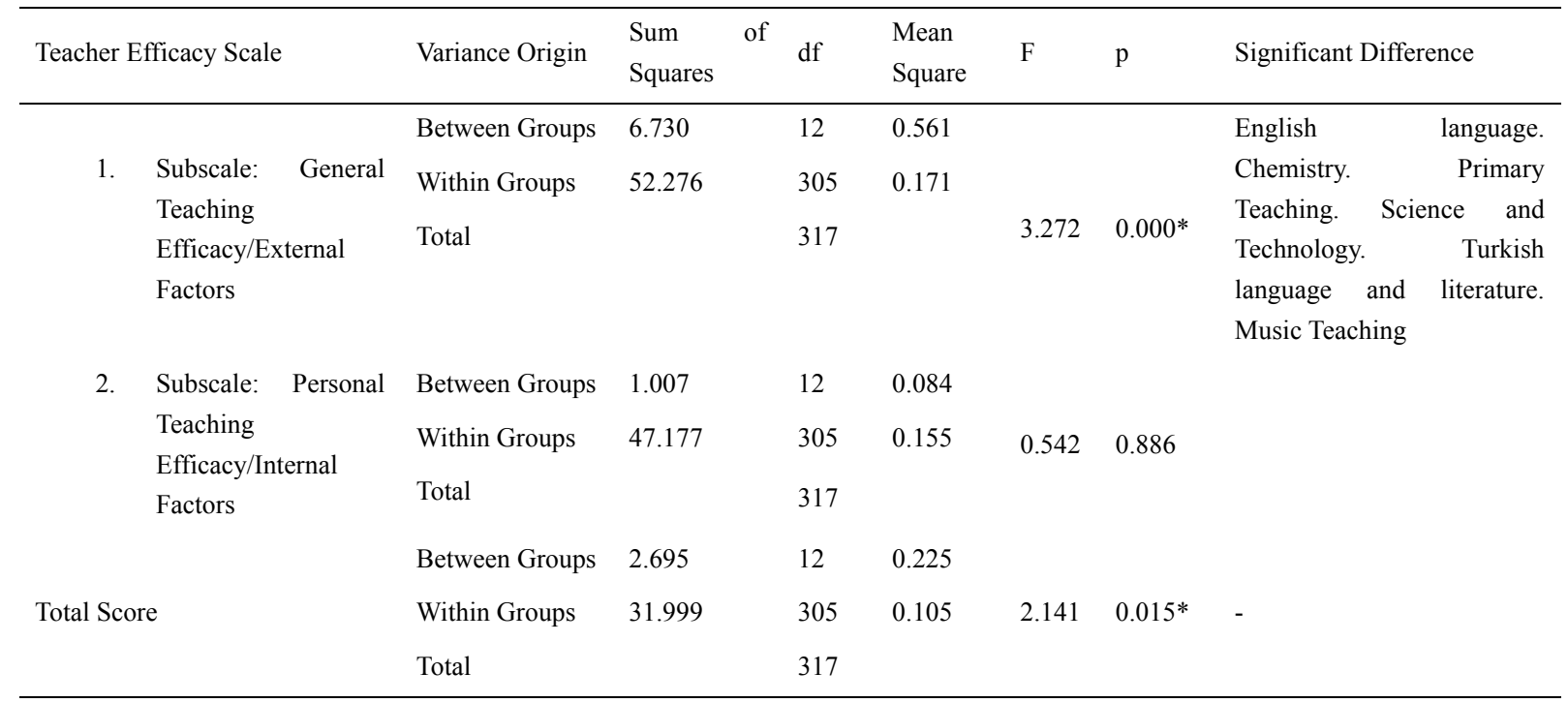

$* \mathrm{p}<0.05$.

As seen in Table 4, there can be concluded no significant difference in personal teaching efficacy/internal factors subscale of Teacher Efficacy Scale. Yet, it is found a significant difference according to the departments in general teaching efficacy/external factors $[\mathrm{F}(12-305)=3.272 ; \mathrm{p}<0.05]$. It is also presented that total score of the Teacher Efficacy Scale differ significantly according to the departments $[F(12-305)=2.141 ; p<0.05]$. Bonferroni post-hoc is used in order to reveal the variance origin. According to the post-hoc analysis, this significant difference is in favor of the department which are English language, Elementary School teaching, Chemistry, Science and Technology and Turkish language and literature among English language, Elementary School teaching, Chemistry, Science and Technology, Turkish language and literature and Music teaching. Although there has been observed a significant difference according to ANOVA results in total score, there has not been detected any significant difference according to the post-hoc analysis. 
Table 5 presents the result of Pearson Correlation analysis to investigate the relationship between the scores obtained from Teacher Efficacy Scale and Emotional Literacy Scale.

Table 5. Correlation results between Emotional Literacy Scale and Teacher Efficacy Scale

\begin{tabular}{llll}
\hline & & Emotional Literacy Scale & Teacher Efficacy Scale \\
\hline \multirow{2}{*}{ Emotional Literacy Scale } & Pearson Correlation & 1 & $0.199^{* *}$ \\
& Sig. (2-tailed) & & 0.000 \\
& N & 318 & 318 \\
Teacher Efficacy Scale & Pearson Correlation & $0.199^{* *}$ & 1 \\
& Sig. (2-tailed) & 0.000 & \\
& $\mathrm{~N}$ & 318 & 318 \\
\hline
\end{tabular}

As shown in Table 5, between the scores obtained from the Emotional Literacy and Teacher Efficacy Scales, positive little relationship was confirmed.

\section{Discussion}

In previous studies, emotional literacy was tried to be measured by emotional intelligence scales because it was a concept close to one another. In this study, research was designed using a scale that directly measures emotional literacy.

The finding for the first research question revealed that in emotional literacy scale total score and social competence subscale score, there is a significant difference in favor of female preservice teachers. There are other researches supporting this finding (Harrod \& Scheer, 2005; Katyal \& Awasthi, 2005; Sevindik, Uncu, \& Güneş-Dağ, 2012).

When the findings of the second research question were studied, preservice teachers showed a significant difference in emotional awareness and emotional self-efficacy subscales of Emotional Literacy Scale according to their department. Based on this finding, it can be expressed that in emotional awareness subscale, the significant difference is in favor of the music teaching preservice teachers among music teaching and computer and instructional technologies. Another significance difference is detected in emotional self-efficacy subscale. The difference in this subscale is in favor of the computer and instructional technologies department preservice teachers compared to history teaching department preservice teachers. When these findings are analyzed, it can be concluded that the reason why music teaching department preservice teachers' score is significantly higher than computer and instructional technologies department preservice teachers in emotional awareness subscale might be because that the schedule of music teaching department consists of art lessons and has an effect on affective variables. The reason why computer and instructional technologies department preservice teachers scored significantly higher than history teaching department preservice teachers in emotional efficacy subscale might be due to the belief of CIT preservice teachers' on their self-perception skills of dealing with emotional problems.

The findings of the third question are that preservice teachers' self-efficacy levels show significant differences in favor of female preservice teachers according to the gender in total score and general teaching efficacy/external factors subscale. There have been evidences in the literature supporting this finding (Gökdağ, 1996; Eminoğlu-Küçüktepe, 2007; Andersen, 2011). This result might be because those female students consider themselves appropriate for the profession and have the belief that they can do it better.

According to the findings of the fourth research question, preservice teachers' self-efficacy levels show significant differences on the basis of the departments. In general teaching efficacy/external factors subscale, the scores are in favor of English language, Chemistry, Elementary School teaching, science and technology and Turkish language and literature departments among English language, Chemistry, Elementary School teaching, science and technology, Music and Turkish language and literature. It was found by Talşık (2016) that music teachers have a lower level of professional efficacy perception. This might be due to the fact that people who are in music teaching department do not consider being teachers in the future and preferring doing music as an art, not as a teaching profession. However, although there happens a significant difference in self-efficacy total score mean according to ANOVA results, post-hoc analysis finds no significant difference. 
It is also determined on the basis of fifth research question that there is a positive relationship between preservice teachers' emotional literacy levels and self-efficacy beliefs. As a result, if preservice teachers' emotional literacy levels rises, their self-efficacy beliefs do the same. In the literature, there has been no research made regarding the relationship between preservice teachers' emotional literacy and their self-efficacy beliefs, there are researches noting that there is relationship between emotional intelligence and self-efficacy beliefs (Amirian \& Behshad, 2016; Şenel, Adiloğulları, \& Ulucan, 2014; Wossenie, 2014; Hashemi, 2011; Salami, 2007; Chan, 2008). Existing researches do support these finding. As explained before, emotional literacy is often used as a synonym with emotional intelligence; however, emotional intelligence is a trait that is from the birth while emotional literacy can be developed afterwards (Wear, 2004; Bocchino, 1999). That's how they are closely related. Due to this close relation between these two variables, it can be thought as naturel that the result of emotional intelligence researches can support this study.

On the basis of the finding of this research, it can be suggested to add courses and events to the schedules of education faculties to foster preservice teachers' emotional literacy as there is a relationship between preservice teachers' emotional literacy and self-efficacy beliefs. After graduation in-service teacher trainings including emotional awareness and emotional literacy can also be proposed to Ministry of National Education to improve self-efficacy.

It is also considered important that psychological counseling and guidance services in higher education, which are not yet common in Turkey but active in some universities, are widely implemented in all universities and that psychoeducation programs for improving the emotional literacy of preservice teachers within these services are developed and implemented.

There are some limitations to this study. First, it is suggested to carry out this specific study again with a broader perspective in order to generalize the findings. As the study group is the preservice teachers, it can be suggested to redo the research with teachers in the field and compare the results. The relationship between emotional literacy and self-efficacy beliefs should be re-investigated with the variables that might affect self-efficacy. Finally, the relationship between emotional literacy skills and teacher job satisfaction, psychological well-being, coping strategies, conflict resolution, etc., might be determined in the context of teaching profession.

\section{References}

Ada, S., \& Ünal, S. (2004). Öğretmenlik mesleğine giriş [Introduction to teaching profession]. İstanbul: Marmara Üniversitesi Döner Sermaye İşletmesi Teknik Eğitim Fakültesi Matbaası.

Adeyemo, D. A. (2007). Moderating influence of emotional intelligence on the link between academic self-efficacy and achievement of university students. Psychology Developing Societies, 19(2), 199-213. https://doi.org/10.1177/097133360701900204

Akbağ, M., Eminoğlu Küçüktepe, S., \& Eminoğlu Özmercan, E. (2016). A study on Emotional Literacy Scale development. Journal of Education and Training Studies, 4(5), 85-91. https://doi.org/10.11114/jets.v4i5.1419

Amirian, S. M. R., \& Behshad, A. (2016). Emotional intelligence and self-efficacy of Iranian teachers: A research study on university degree and teaching experience. Journal of Language Teaching and Research, 7(3), 548-558. https://doi.org/10.17507/jltr.0703.16

Andersen, L. B. (2011). Teacher diversity: Do male and female teachers have different self-efficacy and job satisfaction? Paper prepared for the 33rd EGPA conference in Bucharest (7-10 September 2011). Retrieved from https://soc.kuleuven.be/io/egpa/HRM/bucharest/Andersen2011.pdf

Antidote, J. P. (2003). The emotional literacy handbook: Promoting whole-school strategies. London: David Fulton Publishers.

Bandura, A. (1986). Social foundations of thought and action: A social cognitive theory. Englewood, NJ: Prentice-Hall.

Bloom, S. (1979). İnsan nitelikleri ve okulda öğrenme [Human characteristics and school learning] (Çev: D. A. Özçelik). Ankara: MEB Basımevi.

Bocchino, R. (1999). Emotional literacy: To be a different kind of smart. Thousand Oaks, CA: Sage Publications.

Brophy, J. E. (1981). Teacher praise: A functional analysis. Review of Educational Research, 51(1), 5-32. https://doi.org/10.3102/00346543051001005 
Büyükkaragöz, S. (1998). Öğretmenlik mesleğine giriş [Introduction to teaching profession]. Konya: Mikro Basım-Yayın.

Carmeli, A., Yitzhak-Halevy, M., \& Weisberg, J. (2009). The relationship between emotional intelligence and psychological wellbeing. Journal of Managerial Psychology, 24(1), 66-78. https://doi.org/10.1108/02683940910922546

Chan, D. W. (2008). Emotional intelligence, self-efficacy, and coping among Chinese prospective and in-service teachers in Hong Kong. Educational Psychology: An International Journal of Experimental Educational Psychology, 28(4), 397-408. https://doi.org/10.1080/01443410701668372

Dede, Y. (2008). Matematik öğretmenlerinin öğretimlerine yönelik öz yeterlik inançları [Self-Efficacy beliefs of mathemetics teachers toward their teaching]. Türk Eğitim Bilimleri Dergisi, 6(4), 741-757.

Diken, İ. H. (2005). Öğretmen yeterlik ölçeği Türkçe uyarlaması, geçerlik ve güvenirlik çalışması [A Study of validity and reliability of the Turkish version of the teacher efficacy scale]. Eurasian Journal of Educational Research, 16, 102-112.

Doruk, M., \& Kaplan, A. (2012). Sınıf öğretmeni adaylarının matematik öğretimine yönelik özyeterlik inançlarının incelenmesi [Examining prospective primary school teachers' self-efficacy beliefs toward mathematics teaching]. The Journal of Academic Social Science Studies, 5(7), 291-302.

Eminoğlu-Küçüktepe, S. (2007). İlköğretim öğretmenlerinin öz-oluşum türleriyle, mesleki etkililik algıları ve tercih ettikleri ögretme stilleri arasindaki ilişki [The relationships among kinds of self-construal, vocational efficacy perceptions and preferred teaching styles of elementary school teachers] (Yayınlanmamış Doktora Tezi, Unpublished doctoral dissertation). Yıldız Teknik Üniversitesi Sosyal Bilimler Enstitüsü, İstanbul.

Erden, M. (2005). Öğretmenlik mesleğine girişs [Introduction to teaching profession]. İstanbul: Epsilon Yayıncilik.

Gökdağ, M. (1996). Temel eğitim öğretmenleri ile öğrencilerin güdü düzeyleri ve ögrrenci-öğretmen özellikleriyle ilişkileri [Elemantary teacher and student and motivation levels and characteristics of relationships between teacher and student] (Yayınlanmamış Yüksek Lisans Tezi, Unpublished master of art thesis). Dokuz Eylül Üniversite Eğitim Bilimleri Enstitüsü, İzmir.

Hashemi, M. R. (2011). Emotional intelligence and self-efficacy: A case of Iranian EFL university students. International Journal of Linguistics, 3(1). https://doi.org/10.5296/ijl.v3i1.877

Harrod, N. S., \& Scheer, S. D. (2005). An exploration of adolescent emotional intelligence in relation to demographic characteristics. Adolescence, 40(159), 503-512. Retrived from https://www.ncbi.nlm.nih.gov/pubmed/16268129

Hoy, W. K., \& Woolfolk, A. E. (1990). Socialization of student teachers. American Educational Research Journal, 27, 279-300. https://doi.org/10.3102/00028312027002279

Kandemir, M., \& Dündar, H., (2008). Duygusal okuryazarlık ve duygusal okuryazar öğrenme ortamları [Emotional literacy and emotionally literate learning environments]. Sakarya Üniversitesi Eğitim Fakültesi Dergisi, 16, 83-90.

Karasar, N. (2005). Bilimsel araşstırma yöntemi [Scientific research methods]. Ankara: Nobel Yayın Dağıtım.

Katyal, S., \& Awasthi, E. (2005). Gender differences in emotional intelligence among adolescents of Chandigarh. Journal Human Ecology, 17(2), 53-155.

Küçükahmet, L. (2000). Öğretmenlik mesleğine giriş [Introduction to teaching profession]. Ankara: Nobel Yayınları.

Liau, A. K., Liau, A. W. L., Teoh, G., \& Liau, M. T. L. (2003). The case for emotional literacy: The influence of emotional intelligence on problem behaviours in Malaysian secondary school students. Journal of Moral Education, 32(1), 51-66. https://doi.org/10.1080/0305724022000073338

Louis, R. A., \& Mistele, J. M. (2011). The differences in scores and self-efficacy by student gender in mathematics and science. International Journal of Science and Mathematics Education, Online First, 1-28. Retrived from http://www.sciepub.com/reference/78765

Matsumoto, R. I. M. (2012). Emotional literacy in schools, dropout prevention in Latino middle school students using emotional literacy. A research paper presented to the faculty of Adler graduate school, In partial fulfillment of the requirements for the degree of Master of Arts in school counseling. 
Özdemir, S. M. (2008). Sınıf öğretmeni adaylarının öğretim sürecine ilişkin öz yeterlik inançlarının çeşitli değişkenler açısından incelenmesi [An investigation of prospective primary teachers' self-efficacy beliefs regarding teaching process in terms of certain variables]. Kuram ve Uygulamada Eğitim Yönetimi [Educational Administration: Theory and Practice], 54, 277-306.

Peterson, P. L., Fennema, E., Carpenter, T. P., \& Loef, M. (1989). Teachers' pedagogical content beliefs in mathematics. Cognition and Instruction, 6(1), 1-40. https://doi.org/10.1207/s1532690xci0601_1

Salami, S. O. (2007). Relationships of emotional intelligence and self-efficacy to work attitudes among secondary school teachers in Southwestern Nigeria. Pakistan Jornal of Social Sciences, 4(4), 540-547.

Sevindik, F., Uncu, F., \& Güneş-Dağ, D. (2012). Sağlık yüksekokulu öğrencilerinin duygusal zeka düzeylerinin bazı değişkenler açısından incelenmesi [The investigation of emotional intelligence in health school students to some variables]. Firat Üniversitesi Sağllk Bilimleri Tıp Dergisi [Firat University Medical Journal of Health Sciences], 26(1), 21-26. Retrived from http://tip.fusabil.org/pdf/pdf_FUSABIL_836.pdf

Smith, J. P. (1996). Efficacy and teaching mathematics by telling: A challenge for reform. Journal for Research in Mathematics Education, 27(4), 387-402. https://doi.org/10.2307/749874

Steiner, C. M. (1996). Emotional literacy training: The application of transactional analysis to the study of emotions. Transactional Analysis Journal, 26(1), 31-39. https://doi.org/10.1177/036215379602600107

Steiner, C. M. (2003). Emotional literacy: Intelligence with a heart. Fawnskin, CA: Personhood Press.

Swars, S., Hart, L. C., Smith, S. Z., Smith, M. E., \& Tolar, T. A. (2007). Longitudinal study of elementary pre-service teachers' mathematics beliefs and content knowledge. Elementary Pre-Service Teachers' Mathematics, 107(9), 325-335. https://doi.org/10.1111/j.1949-8594.2007.tb17797.x

Şenel, E., Adiloğulları, İ., \& Ulucan, H. (2014). Examination of emotional intelligence level, teacher's self-efficacy beliefs and general self-efficacy beliefs of teachers. Niğde Üniversitesi Beden Eğitimi ve Spor Bilimleri Dergisi [Niğde University Journal of Physical Education and Sport Sciences], 8(2), 225-232.

Talşık, E. (2016). Müzik öğretmenlerinin mesleki genel yeterlik algıları ile doyum ve tükenmişlik düzeyleri arasındaki bağıntının incelenmesi [The investigation of relation between perceived professional proficiency, professional satisfaction and burnout levels of in-service music teachers]. Mehmet Akif Ersoy Üniversitesi Ĕgitim Fakültesi Dergisi [Mehmet Akif Ersoy University Journal of Education Faculty], 37, 1-14.

Türkoğlu, A. (1990). 99 soruda eğitim bilimine giriş. Adana: Monet Basım Yayım.

Weare, K. (2004). Developing the emotionally literate school. London: Sage Publications.

Wossenie, G. (2014). Teachers' emotional intelligence and sense of self-efficacy beliefs: A study on second cycle public primary school EFL teachers in Bahir Dar Town, Ethiopia. Science, Technology and Arts Research Journal, 3(2), 213-220. https://doi.org/10.4314/star.v3i2.28

Yıldırım, S. (2011). Öz-yeterlik, içe yönelik motivasyon, kaygı ve matematik başarısı: Türkiye, Japonya ve Finlandiya'dan bulgular [Self-efficacy, intrinsic motivation, anxiety and mathematics achievement: Findings from Turkey, Japan and Finland]. Necatibey Eğitim Fakültesi Dergisi [Necatibey Faculty of Education Electronic Journal of Science and Mathematics Education], 5(1), 277-291.

\section{Copyrights}

Copyright for this article is retained by the author(s), with first publication rights granted to the journal.

This is an open-access article distributed under the terms and conditions of the Creative Commons Attribution license (http://creativecommons.org/licenses/by/4.0/). 